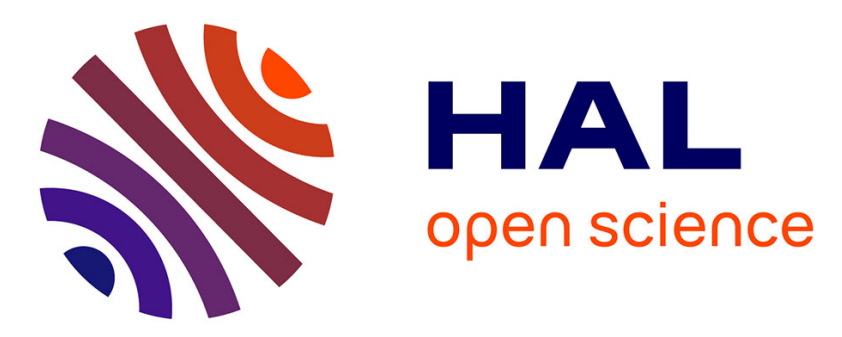

\title{
Experimental and theoretical studies of the structure of tellurate-borate glasses network
}

\author{
Simona Rada, Eugen Culea, Manfred Neumann
}

\section{To cite this version:}

Simona Rada, Eugen Culea, Manfred Neumann. Experimental and theoretical studies of the structure of tellurate-borate glasses network. Journal of Molecular Modeling, 2010, 16 (8), pp.1333-1338. 10.1007/s00894-009-0641-8 . hal-00562269

\section{HAL Id: hal-00562269 \\ https://hal.science/hal-00562269}

Submitted on 3 Feb 2011

HAL is a multi-disciplinary open access archive for the deposit and dissemination of scientific research documents, whether they are published or not. The documents may come from teaching and research institutions in France or abroad, or from public or private research centers.
L'archive ouverte pluridisciplinaire HAL, est destinée au dépôt et à la diffusion de documents scientifiques de niveau recherche, publiés ou non, émanant des établissements d'enseignement et de recherche français ou étrangers, des laboratoires publics ou privés. 


\section{Editorial Manager(tm) for Journal of Molecular Modeling Manuscript Draft}

Manuscript Number: JMM0429R1

Title: Experimental and theoretical studies of the structure of tellurate-borate glasses network

Article Type: Original paper

Keywords: Tellurate-borate glasses, FT-IR spectroscopy, DFT calculations.

Corresponding Author: Researcher Dr Rada Simona,

Corresponding Author's Institution:

First Author: Rada Simona

Order of Authors: Rada Simona; Manfred Neumann, Prof. Dr; Eugen Culea, Prof. Dr

Abstract: The structural properties of the $\mathrm{xTeO} 2^{*}(1-\mathrm{x}) \mathrm{B} 2 \mathrm{O} 3$ glasses $(\mathrm{x}=0.6 ; 0.7)$ were investigated by FT-IR spectroscopy. From the analysis of the FTIR spectra it is reasonable to assume that by increasing of boron ions content, the tetrahedral [BO4] units are gradually replaced by trigonal [BO3] units. The increase in the number of non-bridging oxygen atoms would decrease the connectivity of the glass network and will yield the depolymerization of the borate chains.

The molecular structure and vibrational frequencies of the proposed structural models have been studied by exploring of the density functional theory (DFT) calculations. The FTIR spectra of the $\mathrm{xTe} 02 *(1-\mathrm{x}) \mathrm{B} 2 \mathrm{O} 3$ vitreous systems were compared with the calculated spectrum. This procedure allowed us to assign most of the observed IR bands.

Response to Reviewers: Journal of Molecular Modeling Title: Experimental and theoretical studies of the structure of tellurate-borate glasses network Authors: S. Rada, E. Culea, M. Neumann

Dear Sir,

Thank you for the comments made by you and the referees on our manuscript. Taking into account these observations we operated the following modifications:

\section{Reviewers'comments:}

Reviewer \#1:

Authors have studied the structural properties of xTe02*(1-x)B2O3 (x=0.6; 0.7) glassy network at the both experimental and theoretical methods. On the experimental parts authors have used FTIR technique to record the vibrational frequencies and the B3PW91/3-21G level of theoretical calculation to interpret the experimental vibrational modes. Although, the choice of the basis set is poor, but for the size of the considered system in the investigation the basis set can be acceptable. In fact, the theoretical calculation has predicted the IR spectrum which is in good agreement with experimental results. This work clearly shows that, whenever possible, the application of both the experimental and theoretical methods is best route to interpret complex structures. This is well written manuscript and can be accepted for publication in JMM. 
Authors

We are grateful to the referent for the extremely useful comments.

Reviewer \#2:

1. The manuscript entitled "A theoretical model for binary 0.6Te02.0.4B203 glassy network" by S.Rada, E. Culea, M. Neumann is a combined experimental and theoretical study of the binary compound of glass. The title of this paper seems to be not very appropriate since the study involves both experiment and theory.

Authors

1. We agree the suggestion of the Reviewer and in this view we changed the title of this paper by "Experimental and theoretical studies of the structure of tellurate-borate glasses network".

Reviewer \#2:

2. Although two compounds have been characterized using FT-IR, only one compound was investigated theoretically. What happened to the other compound 0.7Te02.0.3B203?

Authors

2. We added our results on the 0.7Te02.0.3B203 glassy network. Reviewer \#2:

3. Figure 3 shows complimentarily between experiment and theory. However, I suggest authors to provide the characteristic experimental IR frequencies that are useful to identify the compound and also the corresponding theoretical frequencies in the form of Table. This will be very helpful for the readers. I also suggest the authors to provide the frequencies that could characterize the different groups such as [Te03], [Te04], etc. in the table and the results should be discussed in the paper.

Authors

3.We added some details concerning to the characteristics of the theoretical IR spectra in the Table 3. We renounced at Fig. 3.

Reviewer \#2:

4. Authors revealed that the glass structures consist of selected groups [Te03], [Te04], etc. It is necessary to show these groups clearly by marking in the structure given in Figure 2.Some atoms are missing in Figure 2. It is my concern that figure 2 is not of very good quality. I strongly suggest authors to give very nice (beautiful three-dimensional) picture. Te-O bond length is not given in Figure 2 . Authors

4. We substituted the Fig. 2 by a three-dimensional picture. The Te-0, B-O bond lengths are given in Table 3.

Reviewer \#2:

5. Why authors write absorption spectrum? It will be clear if they write IR spectrum.

Authors

5. We substituted "absorption spectrum" by "IR spectrum".

Reviewer \#2:

6. Authors must state how they calculated total energy/atom of the compound in the paper. Authors

6. The total energy/atom $=$ Hartree-Fock energy / total number of atoms of the compound.

Reviewer \#2:

7. There are several spelling mistakes, some fancy words (like requirest in page 2), grammatical errors in some places, repletion (sentences are different but give same meaning, see 2nd paragraph in page 2). In page 4, "impossibility of to synthesize" may be written as "difficulty in synthesizing". In page 5 , some sentences are not clear; the writing of "bond length decrease easy" is incorrect. This paragraph should be rewritten. Overall, this paper appears to be sort of incomplete and written in urgency. In my opinion, 
this paper may be accepted for publication if authors carefully revise by following the above comments and rewrite some sections to be readable.

Authors

7. We corrected the language in the revised manuscript. We substituted "impossibility of to synthesize" by "difficulty in synthesizing".

The authors thank the reviewers and the editor for their extremely useful comments.

Cluj-Napoca

27.11.2009

Dr. Simona Rada 


\title{
Experimental and theoretical studies of the structure of tellurate- borate glasses network
}

Received: 06.05.2008 / Accepted: 15.12.2009

Simona Rada ${ }^{1, \bowtie}$, Eugen Culea $^{1}$, and Manfred Neumann ${ }^{2}$

${ }^{1}$ Department of Physics, Technical University of Cluj-Napoca, 400641 Cluj-Napoca, Romania

${ }^{2}$ Faculty of Physics, University of Osnabruck, 49069 Osnabruck, Germany

${ }^{\square}$ E-mail: Simona.Rada@phys.utcluj.ro, radasimona@yahoo.com

\begin{abstract}
The structural properties of the $\mathrm{xTeO}_{2} \cdot(1-\mathrm{x}) \mathrm{B}_{2} \mathrm{O}_{3}$ glasses $(\mathrm{x}=0.6 ; 0.7)$ were investigated by FT-IR spectroscopy. From the analysis of the FTIR spectra, it is reasonable to assume that by increasing of boron ions content, the tetrahedral $\left[\mathrm{BO}_{4}\right]$ units are gradually replaced by the trigonal $\left[\mathrm{BO}_{3}\right]$ units. The increase in the number of non-bridging oxygen atoms would decrease the connectivity of the glass network and will yield the depolymerization of the borate chains.

The molecular structure and vibrational frequencies of the proposed structural models have been studied by exploring of the density functional theory (DFT) calculations. The FTIR spectra of the $\mathrm{xTeO}_{2} \cdot(1-\mathrm{x}) \mathrm{B}_{2} \mathrm{O}_{3}$ vitreous systems were compared with the calculated spectrum. This procedure allowed us to assign most of the observed IR bands.
\end{abstract}

Keywords Tellurate-borate glasses $\cdot$ FT-IR spectroscopy $\cdot$ DFT calculations 


\section{Introduction}

Tellurate glasses have recently gained wide attention because of their potential as hosts of rare earth elements for the development of fibres and lasers covering all the main telecommunication bands [1] and promising materials for optical switching devices [2]. Recently, tellurate glasses doped with rare earth oxides [3] have received great scientific interest because these oxides can modified the optical and physical properties of the tellurate glasses.

It is of fundamental importance in glass science to understand the structural forms that arise in glasses composed of network formers of intermediate strength [4]. The field strength of $\mathrm{Te}^{+4}$ ions is intermediate between the good glass formers and the modifiers. Tellurita $\left(\mathrm{TeO}_{2}\right)$ is only a conditional glass former and require fast-quenching techniques to form a glass [5].

On the other hand, anomalous behavior in properties as a function of composition can usually be explained on the basis of the glasses structure. For example, the initial increase in glass transition temperature with the addition of modifier in borate glasses is due to the formation of $\left[\mathrm{BO}_{4}\right]$ structural units. Similarly, modification of $\mathrm{GeO}_{2}$ glass proceeds initially by formation of $\left[\mathrm{GeO}_{6}\right]$ octahedral structural units. The glass transition temperature and molar volume in tellurates do not show similar anomalies, but the resistance to devitrification does $[6]$.

Most tellurate glasses systems require at least $50 \mathrm{~mol} \% \mathrm{TeO}_{2}$ for glass formation [7]. The building units of these materials include $\left[\mathrm{TeO}_{4}\right]$ trigonal bipyramidal units with lone pair of electrons and $\left[\mathrm{TeO}_{3}\right]$ pyramidal structural units [8].

The main objectives of the present work are to study structural properties of the boratetellurate glasses induced by the modification of the $\mathrm{TeO}_{2}: \mathrm{B}_{2} \mathrm{O}_{3}$ stoechiometry using the FT-IR spectroscopy and DFT calculations. The experimental data permitted to identification of the basic structural units in the studied glasses as well as to follow their interconversion as function of composition. In same time, the present study provides interesting information concerning a new theoretical model of the $\mathrm{xTeO}_{2} \cdot(1-\mathrm{x}) \mathrm{B}_{2} \mathrm{O}_{3}$ glasses network. 


\section{Experimental}

The binary $\mathrm{xTeO}_{2} \cdot(1-\mathrm{x}) \mathrm{B}_{2} \mathrm{O}_{3}, \mathrm{x}=0.6$ and 0.7 glasses were prepared by mixing together specific weights of tellurium dioxide and boric acid, in a ceramic crucibles. The crucible was transferred to a furnace for 60 minutes at $800^{\circ} \mathrm{C}$.

The FT-IR spectra of the glasses in the $400-1600 \mathrm{~cm}^{-1}$ spectral range were obtained with a JASCO FTIR 6200 spectrometer using the standard KBr pallet disc technique. The spectra were carried out with a standard resolution of $2 \mathrm{~cm}^{-1}$.

The densities of the glass samples were measured accurately to the third decimal $\left( \pm 0,03 \mathrm{~g} \mathrm{~cm}^{-}\right.$ ${ }^{3}$ ) by the displacement method using water as an immersion liquid.

The geometry optimization of the proposed structural model was carried out using the density function theory (DFT). The DFT computations were performed with B3PW91/3-21G ${ }^{*}$ method using the Gaussian'03 program package [9]. Dangling bonds of outer atoms of the models were saturated with hydrogen atoms. The structural geometry of borate-tellurate glasses network was completely optimized. The vibrational frequencies and IR intensities were calculated for the equilibrium geometry.

\section{Results and discussion}

The density of glasses is of special importance, especially in the context of the studies of the structural changes. Thus, the abrupt changes of density of the glasses suggest important structural modifications of the vitreous network.

Density measurements show that the density increases by increasing of the molar fraction, $\mathrm{x}$ from $3.91 \mathrm{~g} \mathrm{~cm}^{-3}$ to $4.96 \mathrm{~g} \mathrm{~cm}^{-3}$. This dependence of the density on composition is in agreement with the weight and size of the constituent oxides. On the other hand, the increase in density could be explained considering that the atomic weight of $\mathrm{B}$ atom is smaller than $\mathrm{Te}$ atom and the network may be accommodation by conversion of some $\left[\mathrm{TeO}_{3}\right]$ to $\left[\mathrm{TeO}_{4}\right]$ structural units and $\left[\mathrm{BO}_{3}\right]$ trigonal to $\left[\mathrm{BO}_{4}\right]$ tetrahedral structural units yielding the open structure of glasses.

The FTIR spectra of the tellurate-borate glasses are presented in Fig. 1. IR bands are related directly with the nature and quantity of chemical bonds of the vitreous network. The 
examinations of these spectra show that by increasing of the molar fraction, $\mathrm{x}$, the characteristic IR bands are modified, namely:

i) The broader band located at about $622 \mathrm{~cm}^{-1}$ increases and shifts to bigger wavenumber (645 $\mathrm{cm}^{-1}$ ), then shoulder situated at about $780 \mathrm{~cm}^{-1}$ disappears. These bands are attributed to the stretching vibration between tellurium and nonbridging oxygen atoms of $\left[\mathrm{TeO}_{3}\right]$ trigonal bipyramidal or polyhedral $\left[\mathrm{TeO}_{3+1}\right]$ structural units, Table 1 [10-13]. Some authors consider that the shoulder located at $780 \mathrm{~cm}^{-1}$ can be due the fact that there are more distorted $\left[\mathrm{TeO}_{4}\right]$ structural units in the glasses than in $\mathrm{TeO}_{2}$ reference crystals [14] or the benefit of the one of $\left[\mathrm{TeO}_{3}\right]$ entities [15].

ii) For sample with $\mathrm{x}=0.6$, the larger bands centered in the $820-1150 \mathrm{~cm}^{-1}$ spectral region split in four components located at $\sim 875,975,1025$ and $1120 \mathrm{~cm}^{-1}$. All these bands are attributed to the $\mathrm{B}-\mathrm{O}$ stretching vibration in the $\left[\mathrm{BO}_{4}\right]$ structural units [16-19].

iii) The band centrated at $\sim 1255 \mathrm{~cm}^{-1}$ is attributed to the $\mathrm{B}-\mathrm{O}$ stretching vibrations in $\left[\mathrm{BO}_{3}\right]$ structural units from boroxol rings and shifts to $1243 \mathrm{~cm}^{-1}$.

iv) The intensities of the intense bands located at about 1360 and $1435 \mathrm{~cm}^{-1}$ decrease showing the transformation of the $\left[\mathrm{BO}_{3}\right]$ structural units with varied types of borate groups to the $\left[\mathrm{BO}_{4}\right]$ structural units and the $\left[\mathrm{BO}_{3}\right]$ structural units from boroxol rings [16-19].

$<$ Figure 1>

In brief, the increase of fraction molar, $\mathrm{x}$ yields the modification of coordination number of the Te and $\mathrm{B}$ atoms. The contain in $\left[\mathrm{BO}_{4}\right]$ structural units increases because some $\left[\mathrm{BO}_{3}\right]$ structural units with varied types of borate units were transformed in $\left[\mathrm{BO}_{3}\right]$ structural units from boroxol rings and $\left[\mathrm{BO}_{4}\right]$ structural units. Then, the tellurium coordination can be changed progressively from 3 through $3+1$ to 4 .

$\langle$ Table 1>

These experimental IR results were used to the development of the theoretical models for binary $\mathrm{xTeO}_{2} \cdot(1-\mathrm{x}) \mathrm{B}_{2} \mathrm{O}_{3}$ glasses network. Table 2 shows the dependence of the total energy (per atom) of the $\mathrm{xTeO}_{2} \cdot(1-\mathrm{x}) \mathrm{B}_{2} \mathrm{O}_{3}$ system with molar fraction, $\mathrm{x}$. It comes out that the boratetellurate glasses are thermodynamic stable with the increase of molar fraction, $\mathrm{x}$. The total energy/atom of the $\mathrm{TeO}_{2}$ glass are smaller than the borate-tellurate glasses which might explain probably the difficulty in synthesizing of the pure tellurate glasses without other formers and modifiers. 
$<$ Table 2>

The simulation method used is able to provide a realistic description of the borate-tellurate network structure, which consist of four types of structural units: (i) [ $\left.\mathrm{TeO}_{4}\right]$ trigonal bipyramidal structural units (all of the oxygen atoms are involved in bridged bonds and the tellurium atoms are three-coordinated), (ii) $\left[\mathrm{TeO}_{3}\right]$ pyramidal structural units (in which the oxygen involved in the double bond $\mathrm{Te}=\mathrm{O}$ is nonbridging and the other two oxygens are involved in bridged bonds, (iii) $\left[\mathrm{BO}_{3}\right]$ structural units (containing three-coordinated boron atom from boroxol rings or/and from varied types of borate units) and (iv) $\left[\mathrm{BO}_{4}\right]$ structural units (all of the oxygen are involved in bridged bonds).

The study of structural modifications of the network and the equilibrium geometry was performed by optimization. Fig. 2 illustrates the result obtained form a Gaussian/B3PW91/3$21 \mathrm{G}^{*}$ simulation.

It is known that tellurate structures containing tetravalent Te atoms could contain $\left[\mathrm{TeO}_{3}\right]$ trigonal pyramidal units, $\mathrm{TeO}_{3+1}$ polyhedra with three short distances ranging from 1.86 to $1.95 \AA$, or $\left[\mathrm{TeO}_{4}\right]$ disphenoids, each having a well defined $5 \mathrm{~s}^{2}$ lone pair. $\mathrm{Te}^{+4}$ ions are the lone-pair cation and lone-pair electrons occupy a non-bonding orbital that is stereochemically active and can be regarded as an additional ligand completing the coordination polyhedron. In addition to the lone-pair cations, oxygen ions have low coordination numbers also help to open up the crystal structures.

$<$ Figure $2 \mathrm{a}>$

$<$ Figure $2 b>$

$<$ Table 3a>

$<$ Table 3b>

There are two types of atoms in our models (Fig. 2, Table 3), namely:

i) Tellurium is in tetragonal and trigonal coordination. The Te-O bond lengths in the $\mathrm{TeO}_{\mathrm{n}}$ polyhedron of our models are ranged from 1.69 to $2.03 \AA$. The mean Te-O distances (1.88$1.95 \AA)$ are comparable to that of the Te-O covalent bond distance $(2.15 \AA)$ and the tellurium atoms are strongly bonded to four oxygen atoms giving a trigonal bipyramidal arrangement. This geometry of the $\mathrm{Te}^{+4}$ ions show an asymmetric coordination due to the stereochemically active lone-pair electrons. 
ii) The $\mathrm{B}-\mathrm{O}$ bond distances from the $\left[\mathrm{BO}_{4}\right]$ structural unit are somewhat longer than the $\mathrm{B}-\mathrm{O}$ covalent bond $(1.51 \AA)$ but significantly shorter than the sum of the van der Waals radii (3.52 $\AA$ ). This leads to an unsymmetrical coordination in the structural $\left[\mathrm{BO}_{4}\right]$ units. Such irregular coordination polyhedron of the boron ion was found in bismuth borate compounds [20] and boro-bismuthate glasses [21, 22].

$<$ Figure $3 \mathrm{a}>$

The vibrational properties of these glasses inferred from quantum chemical simulation are interpreted through a comparison with the experimental spectra (Table 3). The evolution of vibrational spectrum of the proposed model is important for understanding the broadeningeffect of the glasses from the experimental FTIR spectrum. Our results show that the Te-O and B-O stretching vibration region of the proposed model is similar to the same region of the glass. A good agreement was found between the theoretical and experimental IR absorption data. Comparing the theoretical and experimental data, we conclude that the performance of the method and basic set used for the prediction of the structural data and vibrational modes for the $\mathrm{xTeO}_{2} \cdot(1-\mathrm{x}) \mathrm{B}_{2} \mathrm{O}_{3}$ glasses is good.

$<$ Figure $3 b>$

The massive vibrations of the $\left[\mathrm{BO}_{3}\right]$ structural units can be coupled each other via $\left[\mathrm{TeO}_{3}\right]$ and $\left[\mathrm{TeO}_{4}\right]$ structural units. This leads to the splitting of the bridge modes and a multiplication of the number of these bands.

The distribution of the electronic states of the HOMO, $\mathrm{HOMO}^{-1}, \mathrm{LUMO}$ and $\mathrm{LUMO}^{+1}$ can be seen in Fig. 3. An interesting finding in these systems is that:

i) The HOMO and $\mathrm{HOMO}^{-1}$ give character of electron donor for the $\left[\mathrm{TeO}_{3}\right]$ structural units of the tellurate network.

ii) The LUMO and $\mathrm{LUMO}^{-1}$ give the character of electron acceptor for the $\left[\mathrm{TeO}_{4}\right]$ structural units of the tellurate network and some $\left[\mathrm{BO}_{\mathrm{n}}\right]$ structural units $(\mathrm{n}=3$, for sample with $\mathrm{x}=0.6$ and $\mathrm{n}=3,4$ for sample with $\mathrm{x}=0.7$ ) of the borate network.

There is a change transfer between the tellurium atoms coordinated +3 and +4 . Also, a charge transfer was yielded between tellurium atom and borate network. This can be explained considering that the tellurate network are flexible to form the appropriate coordination environments with structural units of opposite charge such as $\left[\mathrm{BO}_{4}\right]^{-}$tetrahedral structural 
units where change of the tellurate network provides the needed number of oxygen neighbours.

\section{Conclusions}

Glasses of the $\mathrm{xTeO}_{2} \cdot(1-\mathrm{x}) \mathrm{B}_{2} \mathrm{O}_{3}$ vitreous system were obtained for $\mathrm{x}=0.6$ and 0.7 . The FT-IR studies show that the increase of molar fraction, $\mathrm{x}$ of the tellurate-borate network yield the formation of some $\left[\mathrm{BO}_{4}\right]$ and $\left[\mathrm{TeO}_{4}\right]$ structural units interconnected through Te-O-B bridges and the open of structure of the glasses.

Main results of the DFT calculations show that the thermodynamic stability of the vitreous systems increases by increasing of the molar fraction, $\mathrm{x}$. There is a powerful charge transfer between tellurium atoms coordinated +3 and +4 . The evolution of vibrational spectrum of the proposed models show that the Te-O and B-O stretching vibration region of the proposed model is similar to the same region of the glasses. 


\section{References}

1. Pisarska J (2004) J Non-Cryst Solids 345\&346:382-385

2. Afifi H, Marzouk S, Abd el Aal N (2007) Physica B: Condesed Matter 390:65-70

3. El-Mallawany R (1998) Mater Chem Phys 53:93-120

4. Varshneya AK (1994) Fundamentals of Inorganic Glasses. Academic Press: San Diego

5. Mohameda TA, Shaltout I, Al Yahyaei KM (2006) Spectrochim Acta Part A 64:106-115

6. El-Mallawany R, Abdalla MD, Ahmed IA (2008) Mater Chem Phys 109:291-296

7. Fortes LM, Santos LF, Goncalves MC, Almeida RM, Mattarelli M, Montagna M, Chiasera A, Ferrari M, Monteil A, Chaussedent S, Righini GC (2007) Opt Mater 29:503509

8. Rolli R, Gatterer K, Wachtler M, Bettinelli M, Speghini A, Ajo D (2001) Spectrochim Acta Part A 57:2009-2017

9. Frisch MJ, Trucks GW, Schlegel HB, Scuseria GE, Robb MA, Cheeseman JR, Montgomery JA, Vreven T, Kudin KN, Burant JC, Millam JM, Iyengar SS, Tomasi J, Barone V, Mennucci B, Cossi M, Scalmani G, Rega N, Petersson GA, Nakatsuji H, Hada M, Ehara M, Toyota K, Fukuda R, Hasegawa J, Ishida M, Nakajima T, Honda Y, Kitao O, Nakai H, Klene M, Li X, Knox JE, Hratchian HP, Cross JB, Adamo C, Jaramillo J, Gomperts R, Stratmann RE, Yazyev O, Austin AJ, Cammi R, Pomelli C, Ochterski JW, Ayala PY, Morokuma K, Voth GA, Salvador P, Dannenberg JJ, Zakrzewski VG, Dapprich S, Daniels AD, Strain MC, Farkas O, Malick DK, Rabuck AD, Raghavachari K, Foresman JB, Ortiz JV, Cui Q, Baboul AG, Clifford S, Cioslowski J, Stefanov BB, Liu G, Liashenko A, Piskorz P, Komaromi I, Martin RL, Fox DJ, Keith T, Al-Laham MA, Peng CY, Nanayakkara A, Challacombe M, Gill PMW, Johnson B, Chen W, Wong MW, Gonzalez C, Pople JA (2003) Gaussian 03, Revision A.1. Gaussian Inc, Pittsburgh PA

10. Rada S, Culea E (2009) J Mol Struct 929:1-3:141-148

11. Rada S, Culea M, Rada M, Culea E (2008) J Mater Sci 43:18:6122-6125

12. Rada S, Culea E, Culea M (2008) J Mater Sci 43:19:6480-6485

13. Rada S, Culea M, Culea E (2008) J Phys Chem A 112:44:11251-11255

14. Sabadel JC, Armand P, Cachau-Herreillat D, Baldeck P, Doclot O, Ibanez A, Philippot E (1997) J Solid State Chem 132:411-419 
15. Jeansannetas B, Blanchandin S, Thomas P, Marchet P, Champarnaud-Mesjard JC, MerleMejean T, Frit B, Nazabal V, Fargin E, Le Flem G, Martin MO, Bousquet B, Canioni L, Le Boiteux S, Segonds P, Sarger L (1999) J Solid State Chem 146:2:329-335

16. Shivachev BL, Mincov IP, Kashchieva EP, Dimitriev YB, Smith R, Troev T, (2004) J Non-Cryst Solids 345\&346:108-111

17. Rada S, Culea M, Rada M, Pascuta P, Maties V, Culea E (2009) J Mol Struct 937:1-3:7074

18. Rada S, Culea M, Neumann M, Culea E (2008) Chem Phys Lett 460:196-199

19. Rada S, Ristoiu T, Rada M, Coroiu I, Maties V, Culea E (2010) Mater Res Bull 45:1:6973

20. Valant M, Suvoroy D (2004) J Am Ceram Soc 85:2:355-358

21. Rada S, Pascuta P, Bosca M, Culea M, Pop L, Culea E (2008) Vib Spectrosc 48(2):255258

22. Rada S, Culea E, Bosca M, Culea M, Muntean R, Pascuta P (2008) Vib Spectrosc 48:2: 285-288 
Table 1 Infrared absorption bands and their assignment

\begin{tabular}{|c|c|c|}
\hline \multicolumn{2}{|c|}{ Peak position $\left(\mathrm{cm}^{-1}\right)$} & Assignment \\
\hline \multirow[t]{4}{*}[\mathrm{BO}_{4}]{ units } & $550-630$ & $\begin{array}{l}\text { Bending vibrations of the } \mathrm{BO}_{3}{ }^{3-} \text { isolated } \\
\text { borate units }\end{array}$ \\
\hline & $690-720$ & $\begin{array}{l}\text { Oxygen bridges between two trigonal } \\
\text { atoms }\end{array}$ \\
\hline & $720-780$ & $\begin{array}{l}\text { Oxygen bridges between one tetrahedral } \\
\text { and one trigonal boron atom }\end{array}$ \\
\hline & $900-1100$ & Di-, Tri-, tetra- and penta-borate groups \\
\hline \multirow[t]{3}{*}[\mathrm{BO}_{3}]{ units } & $\begin{array}{l}1190-1240 \\
1240-1350\end{array}$ & $\begin{array}{l}\text { Boroxol rings and ortho-borate groups } \\
\text { Boroxol rings }\end{array}$ \\
\hline & $1350-1400$ & $\mathrm{~B}-\mathrm{O}$ vibration of various borate rings \\
\hline & $1420-1550$ & Penta-, meta- and pyro-borate units \\
\hline \multirow[t]{3}{*}{$\begin{array}{l}\text { Tellurium } \\
\text { ions }\end{array}$} & $400-500$ & $\begin{array}{l}\text { the bending mode of Te-O-Te or O-Te-O } \\
\text { linkages }\end{array}$ \\
\hline & $620-680$ & $\mathrm{Te}-\mathrm{O}$ bonds in $\left[\mathrm{TeO}_{4}\right]$ structural units \\
\hline & $720-780 \mathrm{~cm}^{-1}$ & Te-O bonds in $\left[\mathrm{TeO}_{3}\right]$ structural units \\
\hline
\end{tabular}


Table 2 The total energy/atom of the $\mathrm{xTeO}_{2} \cdot(1-\mathrm{x}) \mathrm{B}_{2} \mathrm{O}_{3}$ system

\begin{tabular}{|c|c|}
\hline System & Total energy/atom [a.u/atom] \\
\hline $0.7 \mathrm{TeO}_{2}$ & -39.92 \\
\hline $0.6 \mathrm{TeO}_{2} \cdot 0.4 \mathrm{~B}_{2} \mathrm{O}_{3}$ & -45.91 \\
\hline $0.7 \mathrm{TeO}_{2} \cdot 0.3 \mathrm{~B}_{2} \mathrm{O}_{3}$ & -49.57 \\
\hline
\end{tabular}


Table 3a Some characteristics of the $0.6 \mathrm{TeO}_{2} \cdot 0.4 \mathrm{~B}_{2} \mathrm{O}_{3}$ glass network

\begin{tabular}{|l|l|l|l|}
\hline \multicolumn{5}{|c|}{$0.6 \mathrm{TeO}_{2} \cdot 0.4 \mathrm{~B}_{2} \mathrm{O}_{3}$} \\
\hline B-O distance $(\AA)$ & Te-O distance $(\AA)$ & $\begin{array}{l}\text { Calculated } \\
\text { spectrum }\end{array}$ & $\begin{array}{l}\text { Experimental } \\
\text { IR spectrum }\end{array}$ \\
\hline B1: $1.35,1.36,1.44$ & $\mathrm{Te} 1: 1.79,1.86,1.94,1.95$ & 445 & 470 \\
\hline B2: $1.36,1.40,1.44$ & Te2: $1.81,1.88,1.91,1.92$ & $614,676,707$ & $624,669,694$ \\
\hline B12: $1.42,1,42,1.46$ & Te3: $1.84,1.88,1.96$ & 738,785 & 757,783 \\
\hline B4: $1.34,1.35,1.44$ & Te4: $1.70,1.83,1.85$ & 836,919 & 877,923 \\
\hline B5: $1.36,1.41,1.46$ & Te5: $1.88,1.91,1.94,1.97$ & 980,1082 & 1007,1028 \\
\hline B6: $1.35,1.39,1.40$ & Te7: $1.70,1.90,1.97$ & 1116,1258 & 1103,1253 \\
\hline B7: $1.37,1.38,1.40,2.41$ & & $1295,1340,1473$ & 1363,1433 \\
\hline B8:1.36, $1.36,1.38$ & & & \\
\hline
\end{tabular}


Table $3 \mathbf{b}$ Some characteristics of the $0.7 \mathrm{TeO}_{2} \cdot 0.3 \mathrm{~B}_{2} \mathrm{O}_{3}$ glass network

\begin{tabular}{|l|l|l|l|}
\hline \multicolumn{5}{|c|}{$0.7 \mathrm{TeO}_{2} \cdot 0.3 \mathrm{~B}_{2} \mathrm{O}_{3}$} \\
\hline B-O distance $(\AA)$ & Te-O distance $(\AA)$ & $\begin{array}{l}\text { Calculated } \\
\text { spectrum }\end{array}$ & $\begin{array}{l}\text { Experimental } \\
\text { IR spectrum }\end{array}$ \\
\hline B1: $1.34,1.38,1.40$ & Te1: $1.82,1.86,1.89,2.03$ & 454 & 475 \\
\hline B2: $1.38,1.38,1.39$ & Te2: $1.82,1.83,1.88,1.92$ & $521,524,576$ & 510,535 \\
\hline B3: $1.35,1.40,3.27$ & Te3: $1.69,1.82,1.83$ & $650,675,678$ & $650,671,680$ \\
\hline B4: $1.36,1.41,1.42$ & Te4: $1.85,1.87,1.92$ & 738,767 & 722,767 \\
\hline B5: $1.36,1.39,1.41,3.05$ & Te5: $1.85,1.87,1.94,2.02$ & 865,876 & 877,914 \\
\hline B6: $1.37,1.38,1.40$ & Te6: $1.82,1.88,1.90,1.98$ & $966,1020,1099$ & $961,1010,1031$ \\
\hline & Te7: $1.84,1.84,1.89,1.93$ & 1165,1285 & 1110,1243 \\
\hline & & $1316,1351,1393$ & $1335,1358,1398$ \\
\hline & & 1428,1506 & 1430,1538 \\
\hline
\end{tabular}




\section{Figure captions}

Fig. 1 FT-IR spectra of $\mathrm{xTeO}_{2} \cdot(1-\mathrm{x}) \mathrm{B}_{2} \mathrm{O}_{3}$ glasses

Fig. 2a Optimized structure of the $0.6 \mathrm{TeO} 2 \cdot 0.4 \mathrm{~B} 2 \mathrm{O} 3$ glasses network

Fig. 2b Optimized structure of the $0.7 \mathrm{TeO}_{2} \cdot 0.3 \mathrm{~B}_{2} \mathrm{O}_{3}$ glasses network

Fig. 3a The distribution of the electronic states of the HOMO, HOMO ${ }^{-1}$, LUMO and $\mathrm{LUMO}^{+1}$ of the proposed model for $0.6 \mathrm{TeO}_{2} \cdot 0.4 \mathrm{~B}_{2} \mathrm{O}_{3}$ glasses network

Fig. 3a The distribution of the electronic states of the HOMO, LUMO ${ }^{-1}$, LUMO and $\mathrm{LUMO}^{+1}$ of the proposed model for $0.7 \mathrm{TeO}_{2} \cdot 0.3 \mathrm{~B}_{2} \mathrm{O}_{3}$ glasses network 


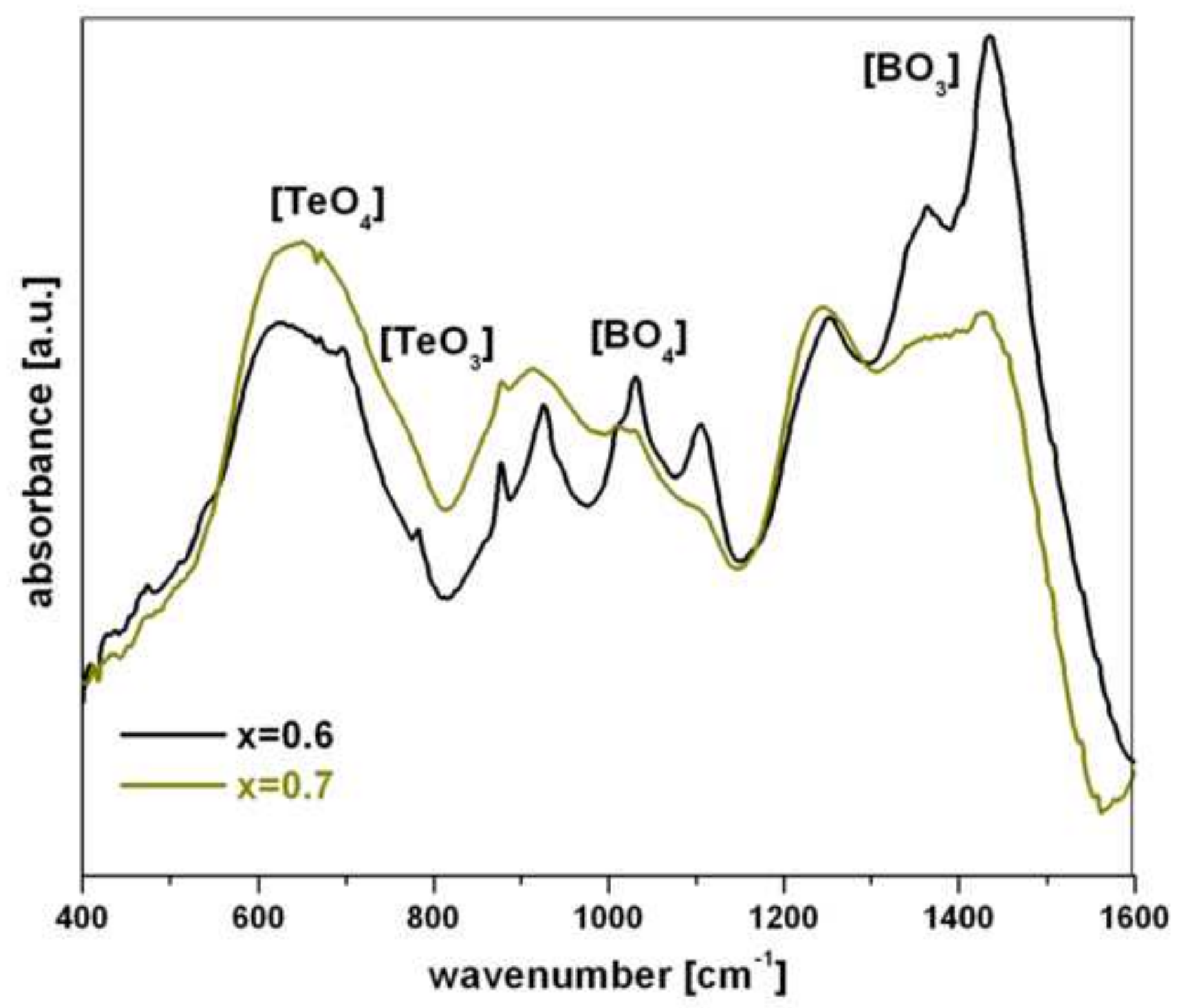




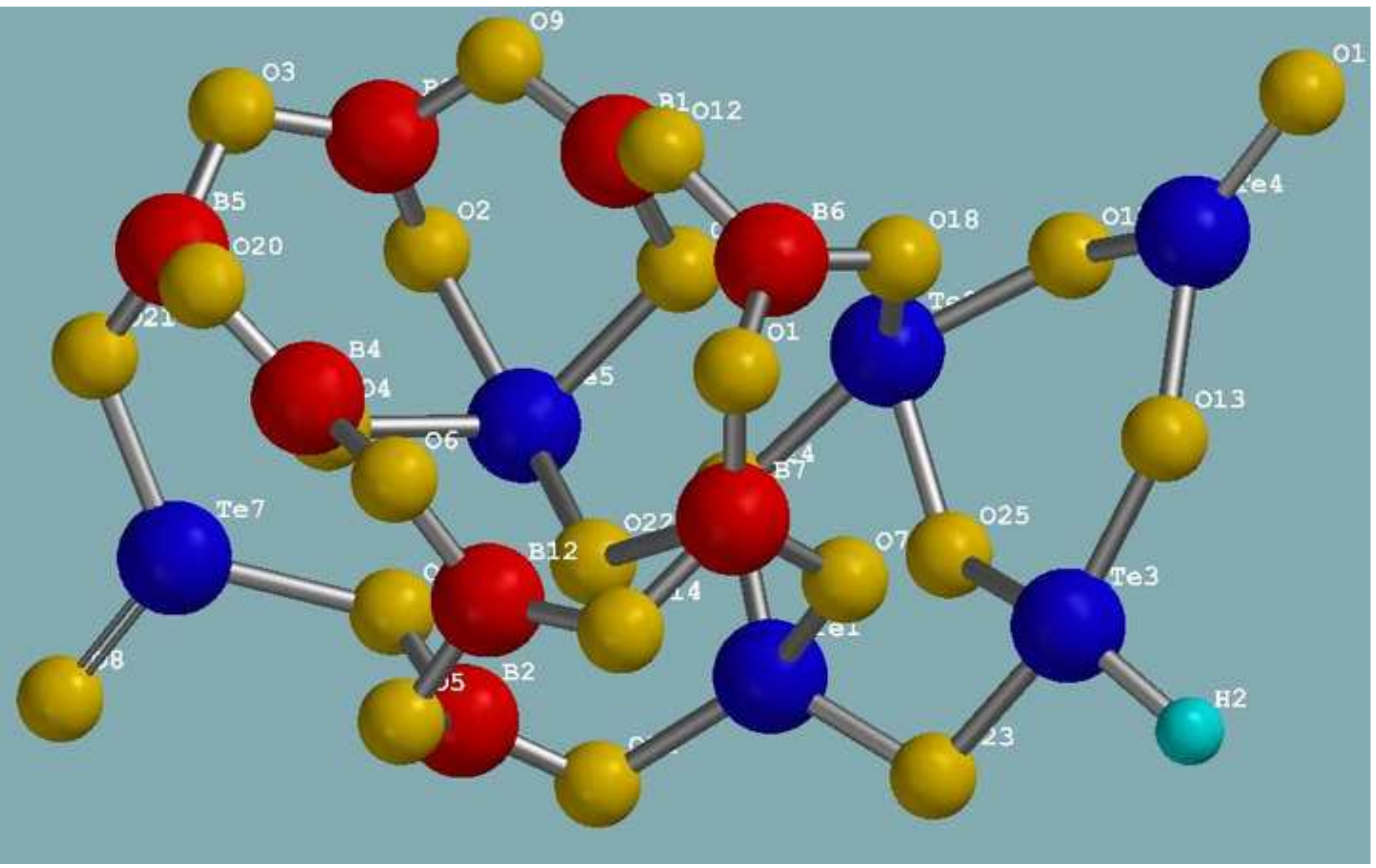




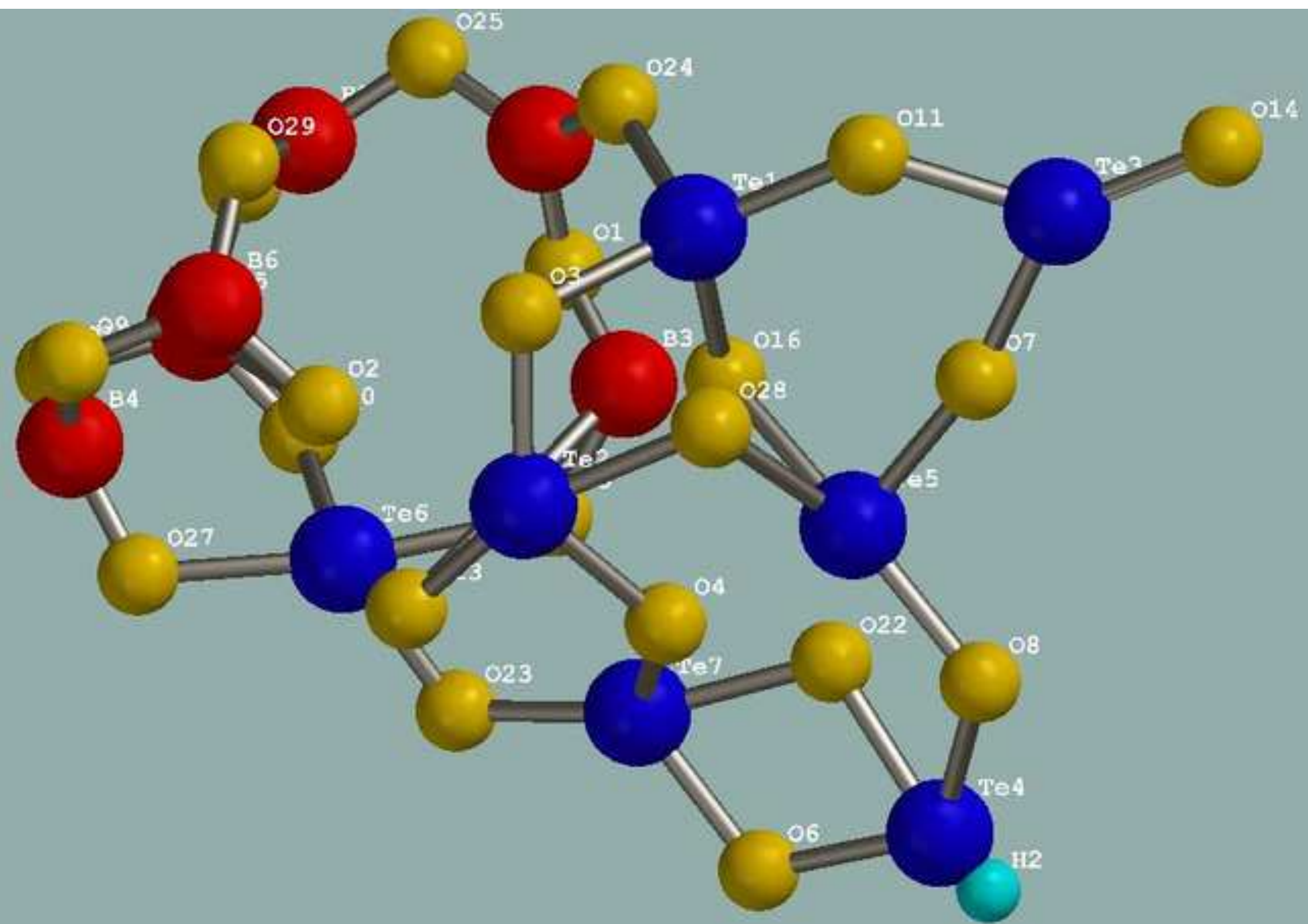



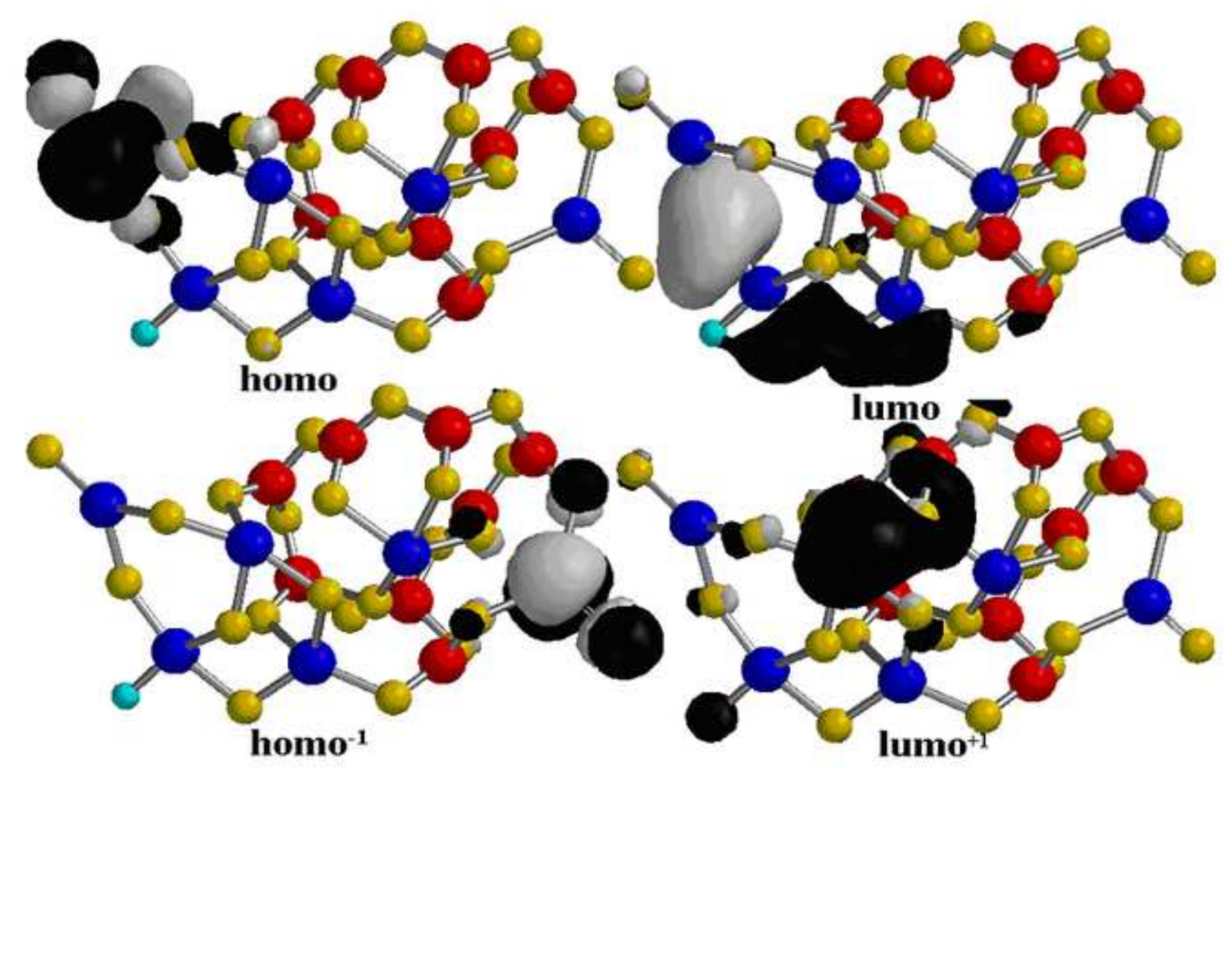

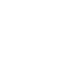


Click here to download high resolution image

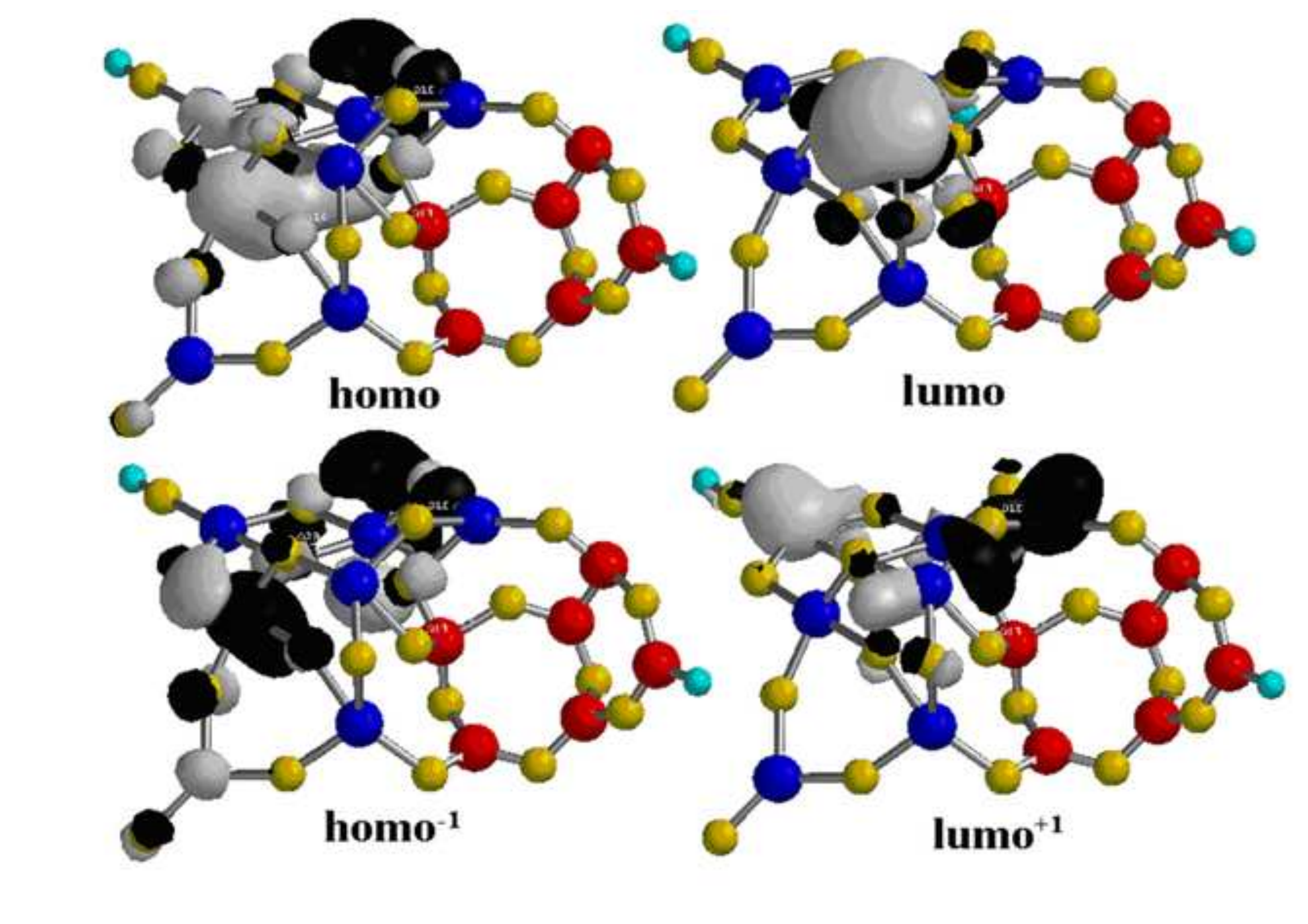

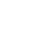

